\title{
Subtidal Habitats of Mermaid Reef (Rowley Shoals), Scott and Seringapatam Reefs, Western Australia.
}

\author{
Peter F. Morrison \\ Sinclair Knight Merz Pty. Ltd. $7^{\text {th }}$ floor Durack Centre, PO Box H615 \\ 263 Adelaide Terrace, Perth, Western Australia 6001, Australia \\ Email: pfmorrison@skm.com.au
}

\begin{abstract}
The sub-tidal habitats at Mermaid (Rowley Shoals), Scott and Seringapatam Reefs were recorded on video during a survey in 2006 and analysed for percentage cover. Recording was undertaken along $25 \mathrm{~m}$ transects at two water depths ( $5 \mathrm{~m}$ and $12 \mathrm{~m}$ relative to mean sea level). The purpose of the video recording was to provide a permanent record of each station while the video transect analysis provided a quantitative description of the benthic habitat to complement semi-quantitative specimen collections.
\end{abstract}

The general benthic cover on the outer reef at Mermaid Reef was at least $60 \%$ sand, rubble or rock (abiotic) while the lagoon sites varied greatly between $23-97 \%$ abiotic cover. The outer reef stations had a higher proportion of encrusting coral while the lagoon stations were more heavily dominated by tabulate and branching corals. The coral morphologies found on the outer reef areas are characteristic of high energy environments, i.e. outer reefs were characterised by the presence of more robust species attached to or encrusting coral rock. The near vertical aspect of the outer reef precluded the deposition of coral sand, which was a major feature of the lagoonal areas. Much of the lagoonal habitat surveyed was associated with bommies, in particular, the slopes and top surfaces.

Unlike the outer reef areas of Mermaid Reef, South Scott Reef had a more gradual slope rather than vertical walls. This slope was often heavily dissected with gutters indicating the high energy nature of the surrounding environment. As a result, the benthic cover at the outer reef stations was at least $40 \%$ abiotic. Like the outer reef stations at Mermaid Reef those at South Scott Reef had a higher proportion of encrusting coral. However, the significant abundance of soft corals, tabulate and digitate corals were in stark contrast. The lagoon stations were more heavily dominated by abiotic cover, in particular, rubble and rock.

All stations at North Scott Reef were dominated by the abiotic categories sand, rubble and rock ranging from $65-95 \%$ cover. The hard corals were dominated by massive and encrusting corals as well as branching corals.

Only two offshore reef stations and one lagoon station were surveyed at Seringapatam Reef, thus, it is difficult to generalise about the habitats of this reef or differences between outer and lagoonal reef habitats. Habitat cover varied from $100 \%$ abiotic at a shallow outer reef transect to $60 \%$ abiotic and $40 \%$ biotic at a deep outer reef transect, with the biotic component comprising soft coral and seven hard coral categories.

\section{AIM}

The purpose of the video recording was to provide a permanent record of each station while the video transect analysis provided a quantitative description of the benthic habitat to complement semi-quantitative specimen collections.

\section{METHODS}

Video recording was undertaken at two depths (approximately $5 \mathrm{~m}$ and $12 \mathrm{~m}$ relative to mean sea level) at each of 32 of a total of 45 surveyed stations in triplicate (three replicate transects) parallel to each other and one metre apart. Recordings were acquired by movement of a Digital Video camera in a housing along $25 \mathrm{~m}$ transects according to the protocol developed by the Australian Institute of Marine Science (Carelton and Done 1995). At each depth a transect was marked by laying a 25 $\mathrm{m}$ measuring tape along the substrate of relatively uniform depth. A SCUBA diver maintained a constant speed of $0.2 \mathrm{~m} / \mathrm{sec}$. and the video was kept $0.5 \mathrm{~m}$ above the surface of the benthic habitat. This captured a band width of approximately $0.6 \mathrm{~m}$ resulting in an area of $15 \mathrm{~m}^{2}$ per transect and $45 \mathrm{~m}^{2}$ for the three transects.

Video recordings of the 32 stations were captured electronically, saved to file and then stored on compact disc. The SKM Video Transect Analysis 


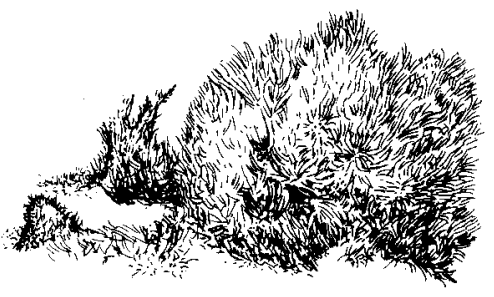

Macroalgae

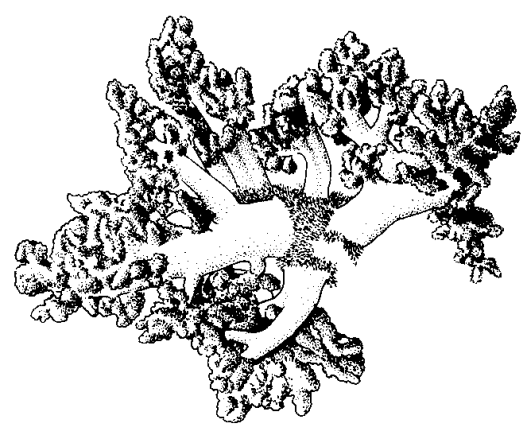

Soft coral

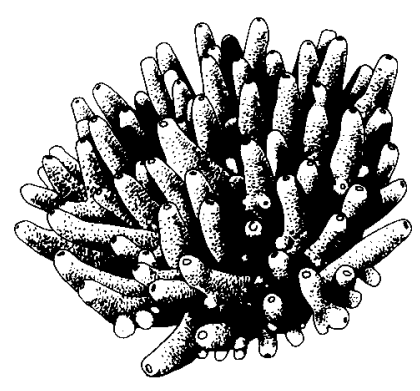

Digitate coral

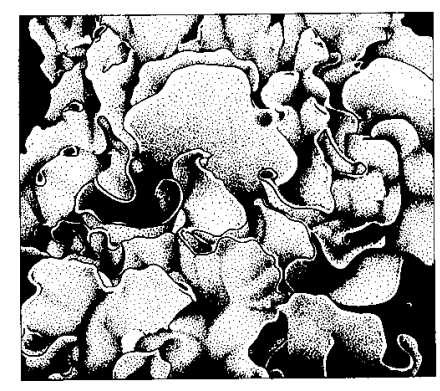

Foliose coral

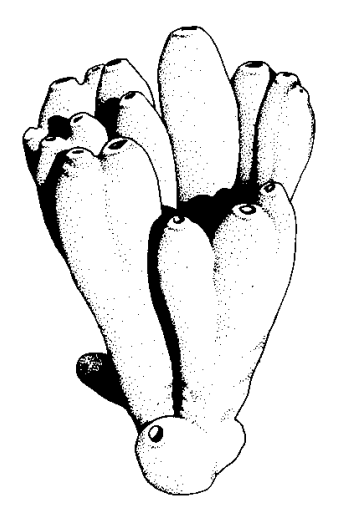

Sponge

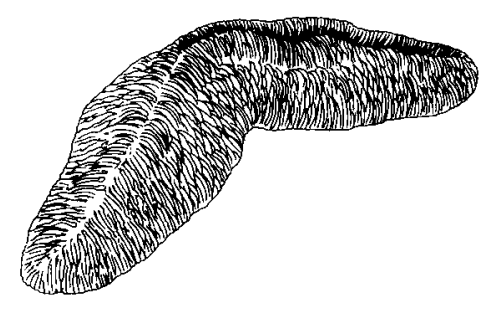

Mushroom coral

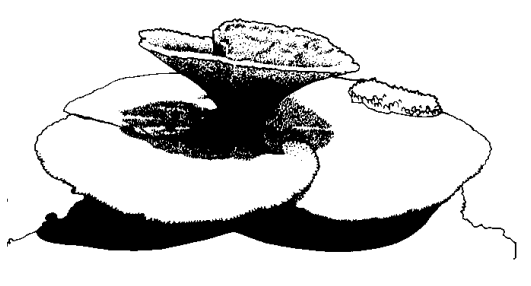

Tabulate coral

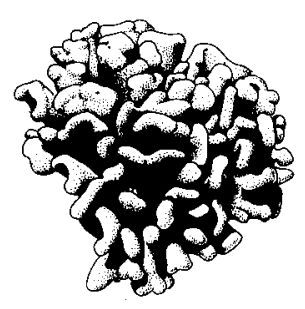

Sub-massive coral

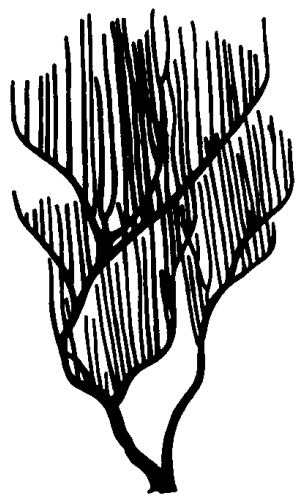

Gorgonian

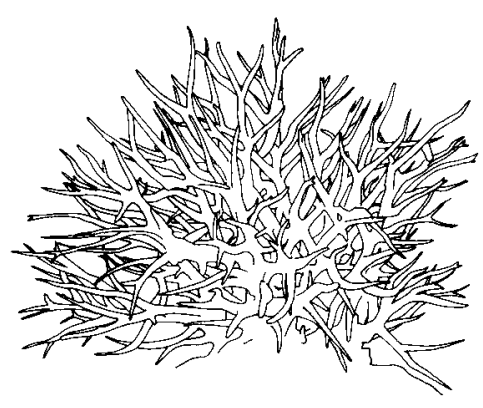

Branching coral

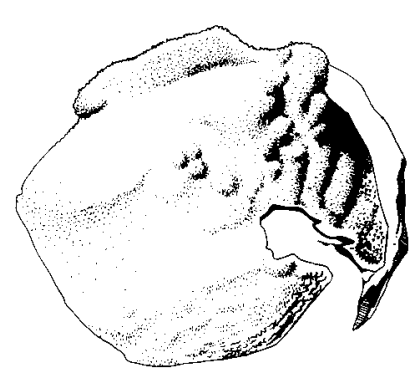

Encrusting coral

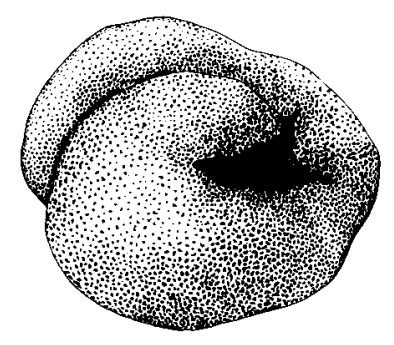

Massive coral

Figure 1 Benthic life-form categories 


\section{MERMAID REEF}

The general description of the physical characteristics of the seabed at each station for Mermaid Reef is presented in Table 1. The mean percentage cover at each station transect is presented graphically by the 15 benthic categories in Figure 2. The data is also presented as percentage cover by a reduced category data set, which amalgamates the abiotic, soft coral and hard coral categories resulting in a set of 5 categories in Figure 3.

Analysis of the data indicates that the outer reef and lagoon transects were distinctly different, particularly the shallow transects in $5 \mathrm{~m}$ of water (see Figure 4 and Figure 5).

The benthic cover at the outer reef stations was at least $60 \%$ abiotic, with the exception of station 2, while the lagoon sites varied greatly between 2397\% abiotic cover (Figure 3). The outer reef stations had a higher proportion of encrusting coral while the lagoon stations were more heavily dominated by tabulate and branching corals (Figure 2).
The coral morphologies found on the outer reef areas were characteristic of high energy environments, i.e. outer reefs were characterised by the presence of more robust species attached to or encrusting coral rock. The near vertical aspect of the outer reef precluded the deposition of coral sand, which was a major feature of the lagoonal areas.

Much of the lagoonal habitat surveyed was associated with bommies, in particular, the slopes and top surfaces. The lagoonal areas were far more protected from wave action were dominated by the more fragile species were deposition areas for coral rubble and sand. The benthic cover differed greatly between the deep (12 m) and shallow (5 m) transects. Much of this variation was associated with the position of the transect on the bommie. The flat seabed around the base of the bommies supported a greater cover of branching coral, whereas the slopes were more sparsely covered by live coral. The tops of bommies were relatively similar in coral cover.

Table 1 Transect topography at Mermaid Reef

\begin{tabular}{l|l|l|l}
\hline Station & Habitat & Depth $(\mathbf{m})$ & Description \\
\hline 1 & Lagoon & 5 & Bommie slope with coral rubble. \\
& & 12 & Relatively flat seabed of fine coral sand and rubble. \\
\hline 2 & Outer reef & 5 & $\begin{array}{l}\text { Reef wall dissected with gutters. } \\
\text { Reef wall dissected with gutters. }\end{array}$ \\
\hline 4 & Outer reef & 5 & $\begin{array}{l}\text { Shallow reef wall from 3m dropping onto coral rubble at 7m. } \\
\text { Reef wall dissected by large gutters with a coral rubble floor. }\end{array}$ \\
\hline 5 & Outer reef & 5 & Near vertical wall. \\
& & 12 & Near vertical wall. \\
\hline 7 & Lagoon & 5 & $\begin{array}{l}\text { Bommie slope with coral rubble. } \\
\text { Relatively flat seabed of fine coral sand and rubble. }\end{array}$ \\
\hline 8 & Lagoon & 5 & $\begin{array}{l}\text { Bommie slope with coral rubble. } \\
\text { Relatively flat seabed of fine coral sand and rubble. }\end{array}$ \\
\hline 9 & Lagoon & 5 & Slope with coral rubble. \\
& & 12 & Relatively flat seabed of fine coral sand and rubble. \\
\hline 11 & Lagoon & 5 & Base of coral bommie. \\
& & 12 & Coral sand with low relief bommies. \\
\hline 12 & Lagoon & 5 & $\begin{array}{l}\text { Top of bommie with undulating surface. } \\
\text { Coral sand with many small bommies. }\end{array}$ \\
\hline 14 & Lagoon & 5 & $\begin{array}{l}\text { Base of coral bommie. } \\
\text { Relatively flat seabed of fine coral sand and rubble. }\end{array}$ \\
\hline 15 & Outer reef & 5 & $\begin{array}{l}\text { Crest of steep drop-off. } \\
\text { Near vertical wall. }\end{array}$ \\
\hline 16 & Outer reef & 5 & $\begin{array}{l}\text { Heavily dissected reef edge. } \\
\text { Gradually sloping seabed with deeply cut gutters. }\end{array}$ \\
\hline & & 12 &
\end{tabular}




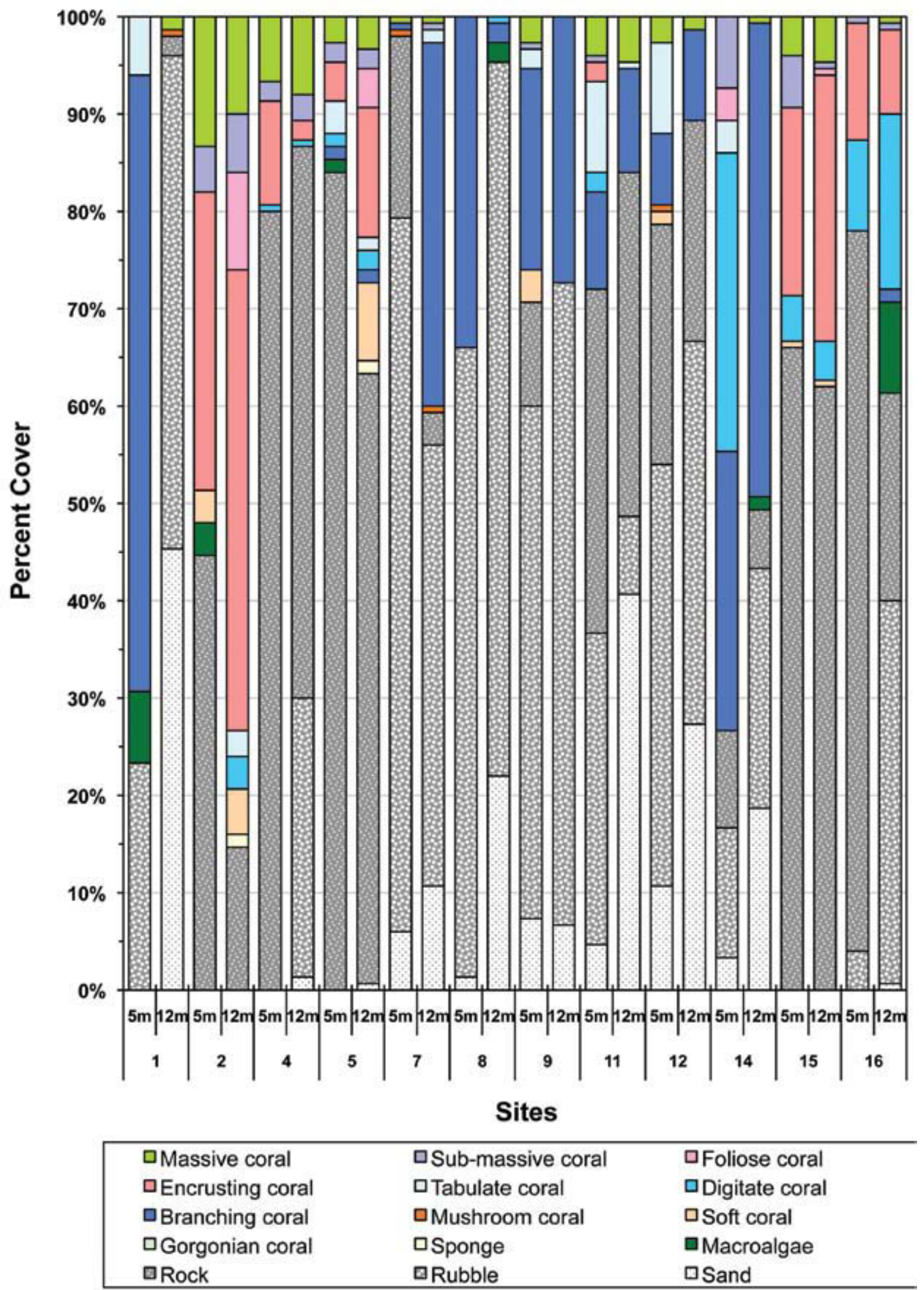

Figure 2 Mermaid Reef habitat cover 


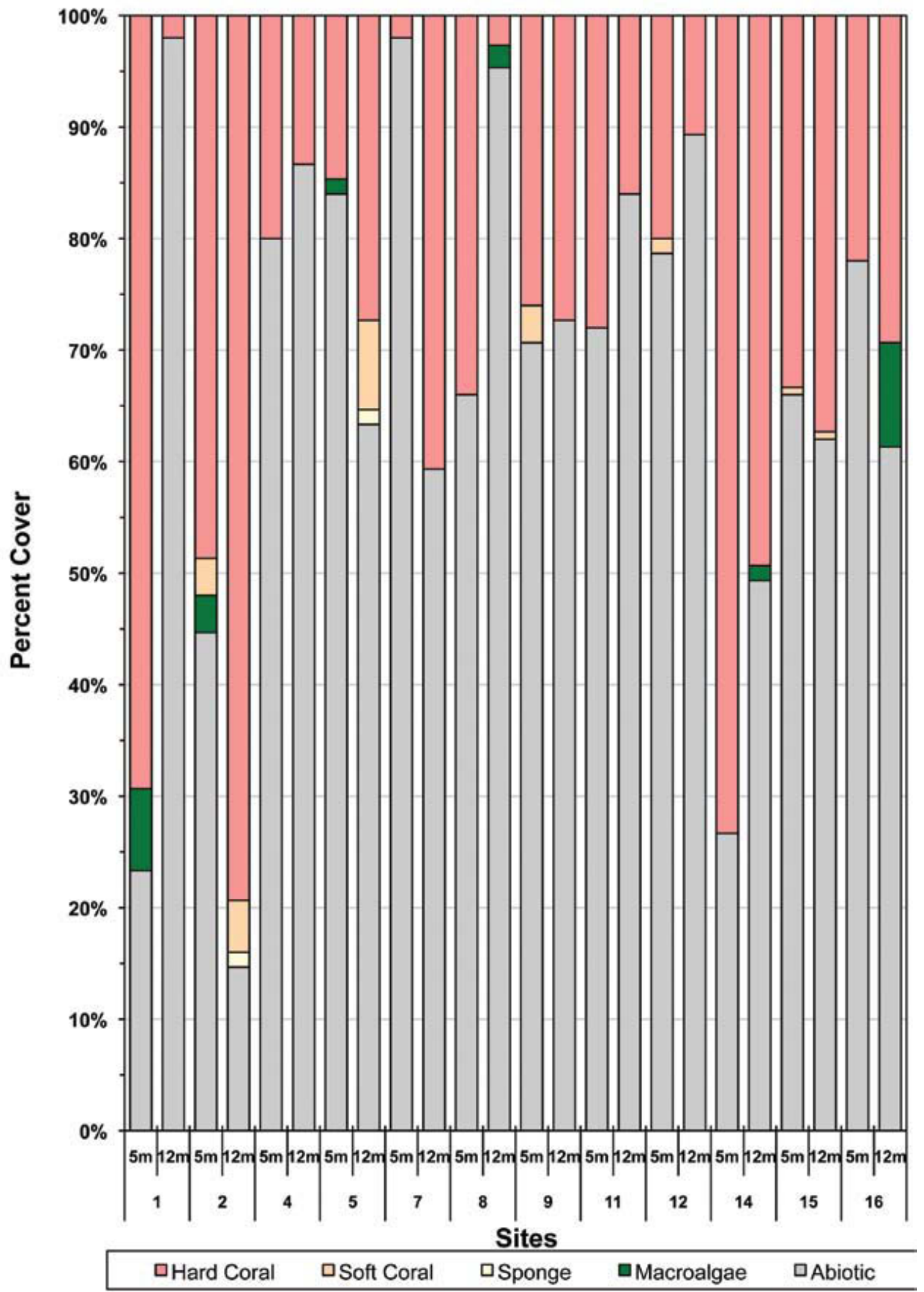

Figure 3 Mermaid Reef grouped habitat cover 


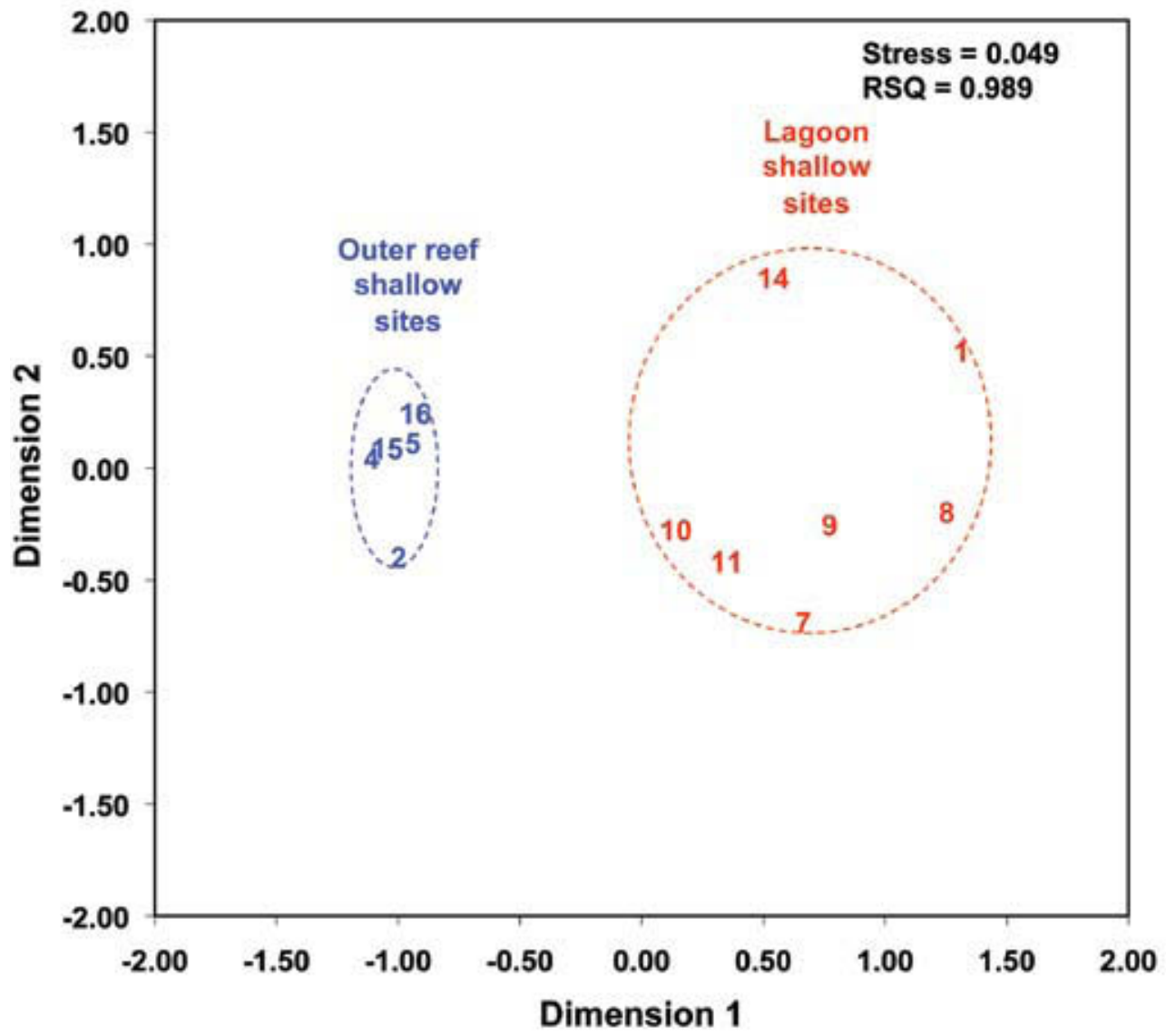

Figure 4 MDS Plot of Mermaid Reef shallow transects

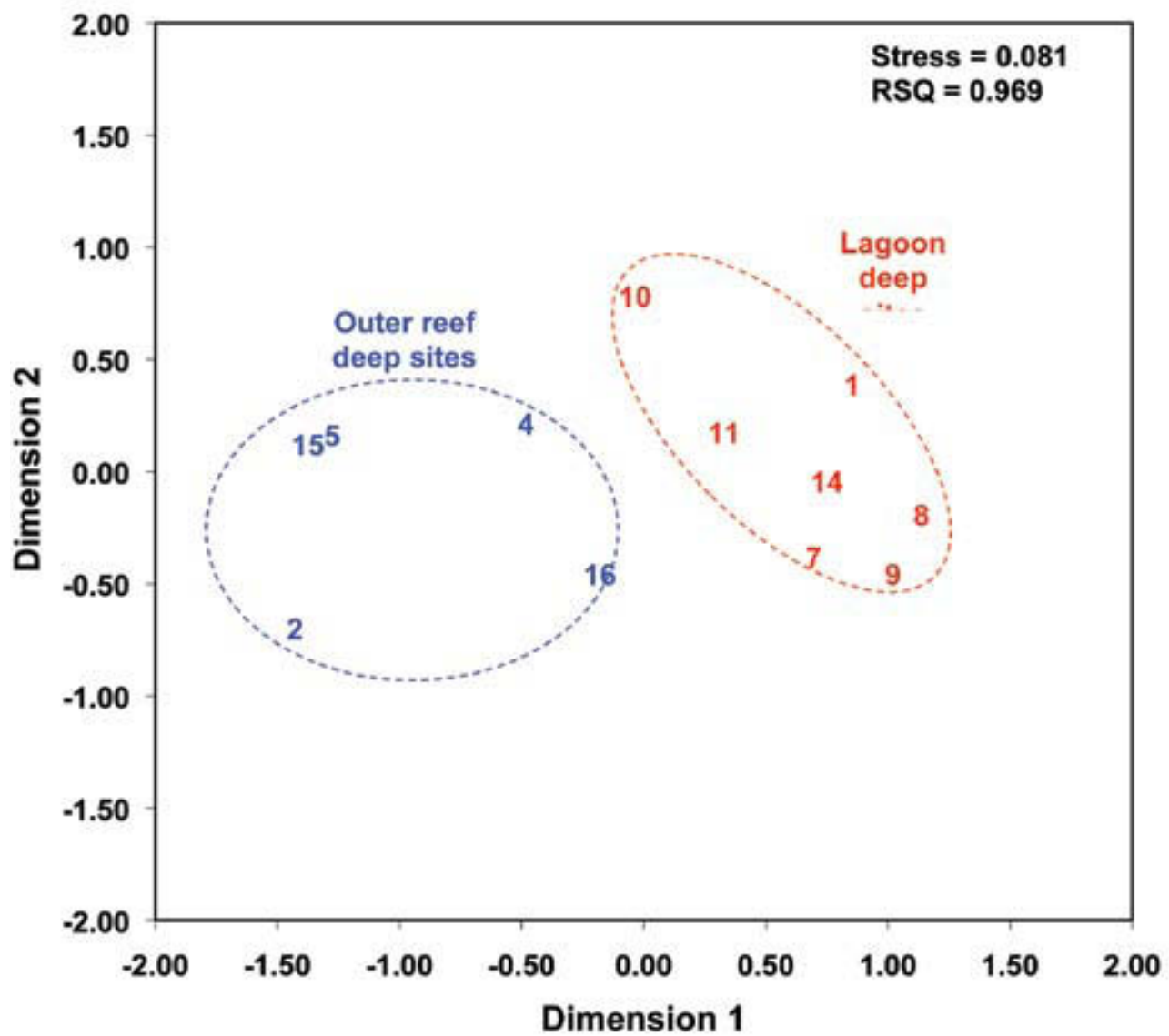

Figure 5 MDS Plot of Mermaid Reef deep transects 


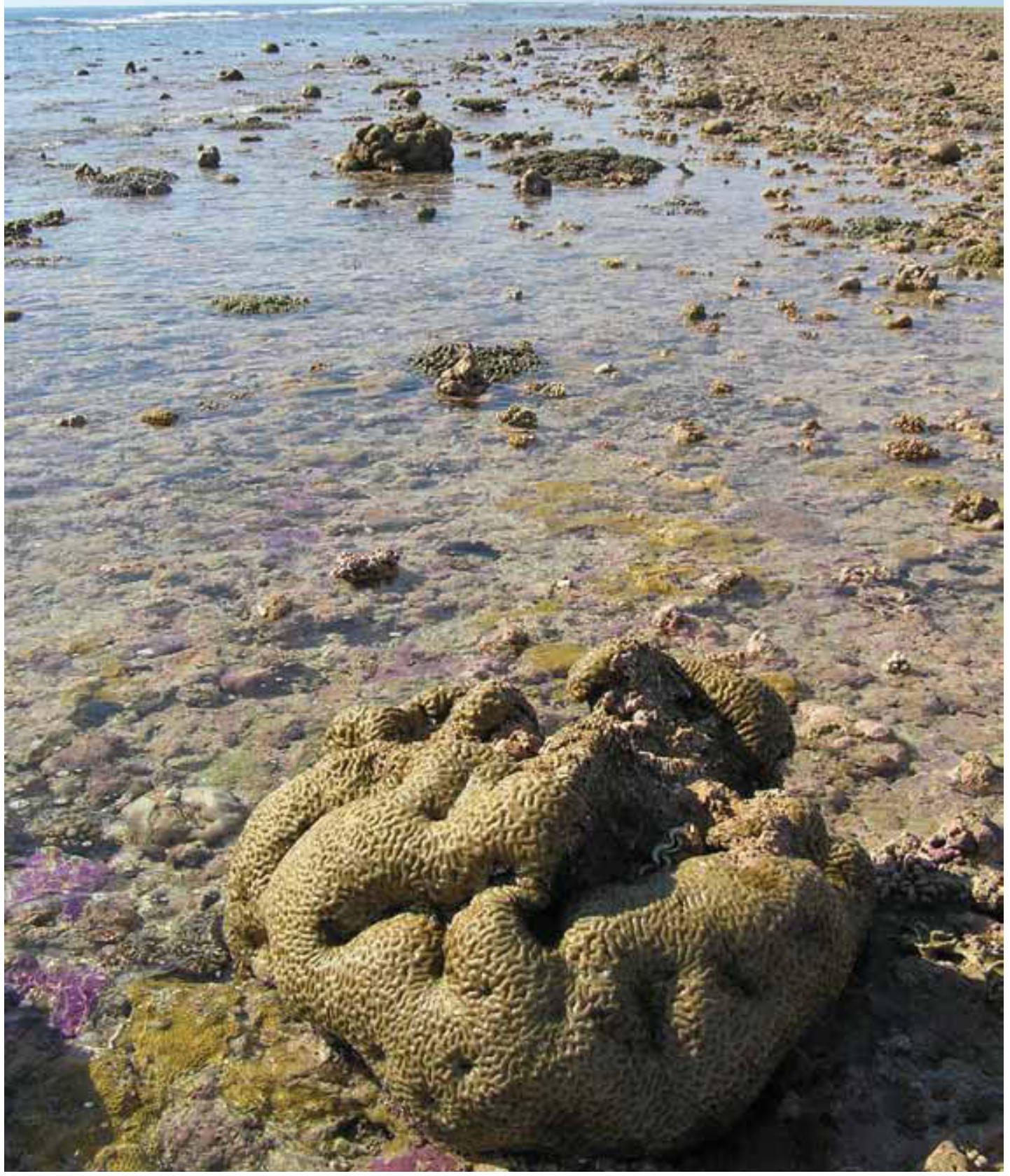

Above: Station 3, Mermaid Reef. Outer reef platform. (Photo: Clay Bryce)

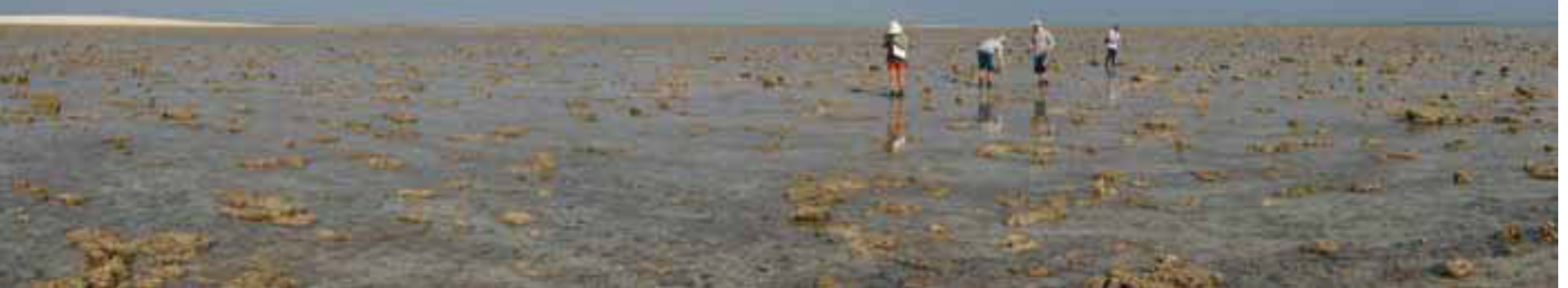

Above: Station 24, South Scott Reef intertidal station. (Photo: John Huisman) 


\section{SOUTH SCOTT REEF}

The general description of the physical characteristics of the seabed at each station for South Scott Reef is presented in Table 2. The mean percentage cover by benthic habitat at each station transect is presented graphically by the 15 benthic categories in Figure 6. The data is also presented as percentage cover by a reduced category data set, which amalgamates the abiotic, soft coral and hard coral categories resulting in a set of 5 categories in Figure 7.

Analysis of the data indicates that the outer reef and lagoon transects were different but less so than was observed at Mermaid Reef (see Figure 8 and Figure 9).

Unlike the outer reef areas of Mermaid Reef, South Scott Reef had a more gradual slope rather than vertical walls. This slope was often heavily dissected with gutters indicating the high energy nature of the surrounding environment. As a result, the benthic cover at the outer reef stations was at least $40 \%$ abiotic (Figure 7). Like the outer reef stations at Mermaid Reef those as South Scott Reef had a higher proportion of encrusting coral. However, the significant abundance of soft corals, tabulate and digitate corals were in stark contrast.

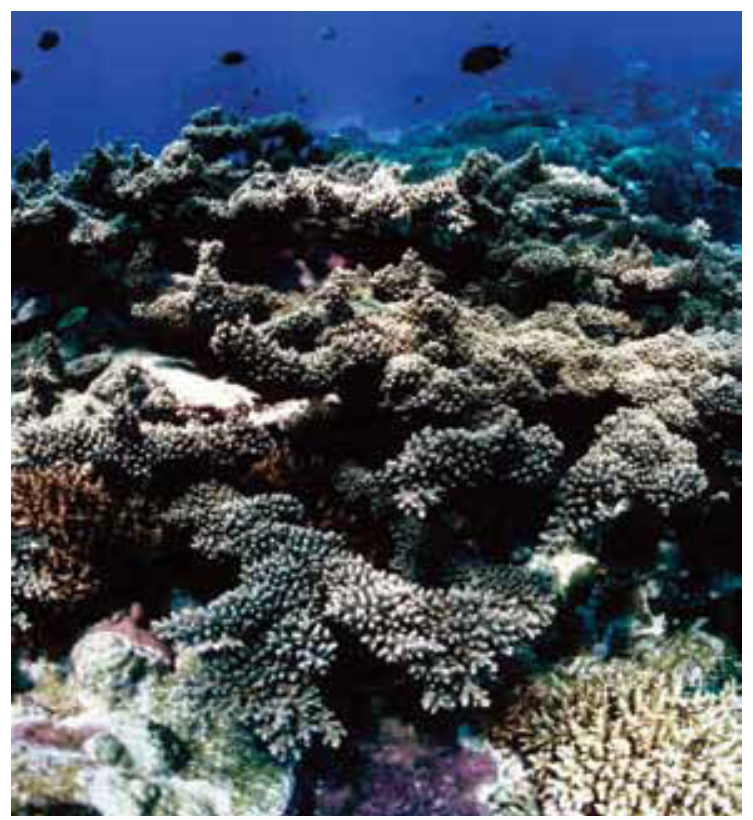

Above: Coral regrowth at South Scott Reef. (Photo: Clay Bryce)

The lagoon stations were more heavily dominated by abiotic cover (Figure 7) and, in particular, rubble and rock (Figure 6). Only the deep transect at station 29 had coral cover similar to that of the outer reef stations.

Table 2 Transect topography at South Scott Reef

\begin{tabular}{|c|c|c|c|}
\hline Station & Habitat & Depth (m) & Description \\
\hline 17 & Outer reef & $\begin{array}{l}5 \\
12\end{array}$ & $\begin{array}{l}\text { Gradual sloping seabed. } \\
\text { Gradual slope towards a steep drop-off. }\end{array}$ \\
\hline 18 & Outer reef & $\begin{array}{l}5 \\
12 \\
\end{array}$ & $\begin{array}{l}\text { Gradual sloping seabed. } \\
\text { Broken reef with high and low relief lumps on sand patches }\end{array}$ \\
\hline 19 & Outer reef & $\begin{array}{l}5 \\
12\end{array}$ & $\begin{array}{l}\text { Gradual slope dissected by gutters. } \\
\text { Gradual sloping seabed. }\end{array}$ \\
\hline 20 & Outer reef & $\begin{array}{l}5 \\
12 \\
\end{array}$ & $\begin{array}{l}\text { Gradual slope dissected by gutters. } \\
\text { Gradual sloping seabed. }\end{array}$ \\
\hline 22 & Outer reef & $\begin{array}{l}5 \\
12 \\
\end{array}$ & $\begin{array}{l}\text { Gradual slope dissected by gutters. } \\
\text { Gradual sloping seabed. }\end{array}$ \\
\hline 23 & Lagoon & $\begin{array}{l}5 \\
12 \\
\end{array}$ & $\begin{array}{l}\text { Top of bommie with a very uneven surface. } \\
\text { Base of bommie with coral rubble. }\end{array}$ \\
\hline 25 & Lagoon & $\begin{array}{l}5 \\
12\end{array}$ & $\begin{array}{l}\text { Top of bommie with a very uneven surface. } \\
\text { Relatively flat seabed of fine coral sand and rubble. }\end{array}$ \\
\hline 26 & Lagoon & $\begin{array}{l}5 \\
12\end{array}$ & $\begin{array}{l}\text { Bommie slope with coral rubble. } \\
\text { Base of coral bommie. }\end{array}$ \\
\hline 28 & Outer reef & $\begin{array}{l}5 \\
12 \\
\end{array}$ & $\begin{array}{l}\text { Heavily dissected reef. } \\
\text { Heavily dissected reef. }\end{array}$ \\
\hline 29 & Lagoon & 12 & Top of bommie with fine coral sand and rubble. \\
\hline 30 & Outer reef & $\begin{array}{l}5 \\
12\end{array}$ & $\begin{array}{l}\text { Heavily dissected reef with very steep gutter sides. } \\
\text { Heavily dissected reef with very steep gutter sides. }\end{array}$ \\
\hline
\end{tabular}




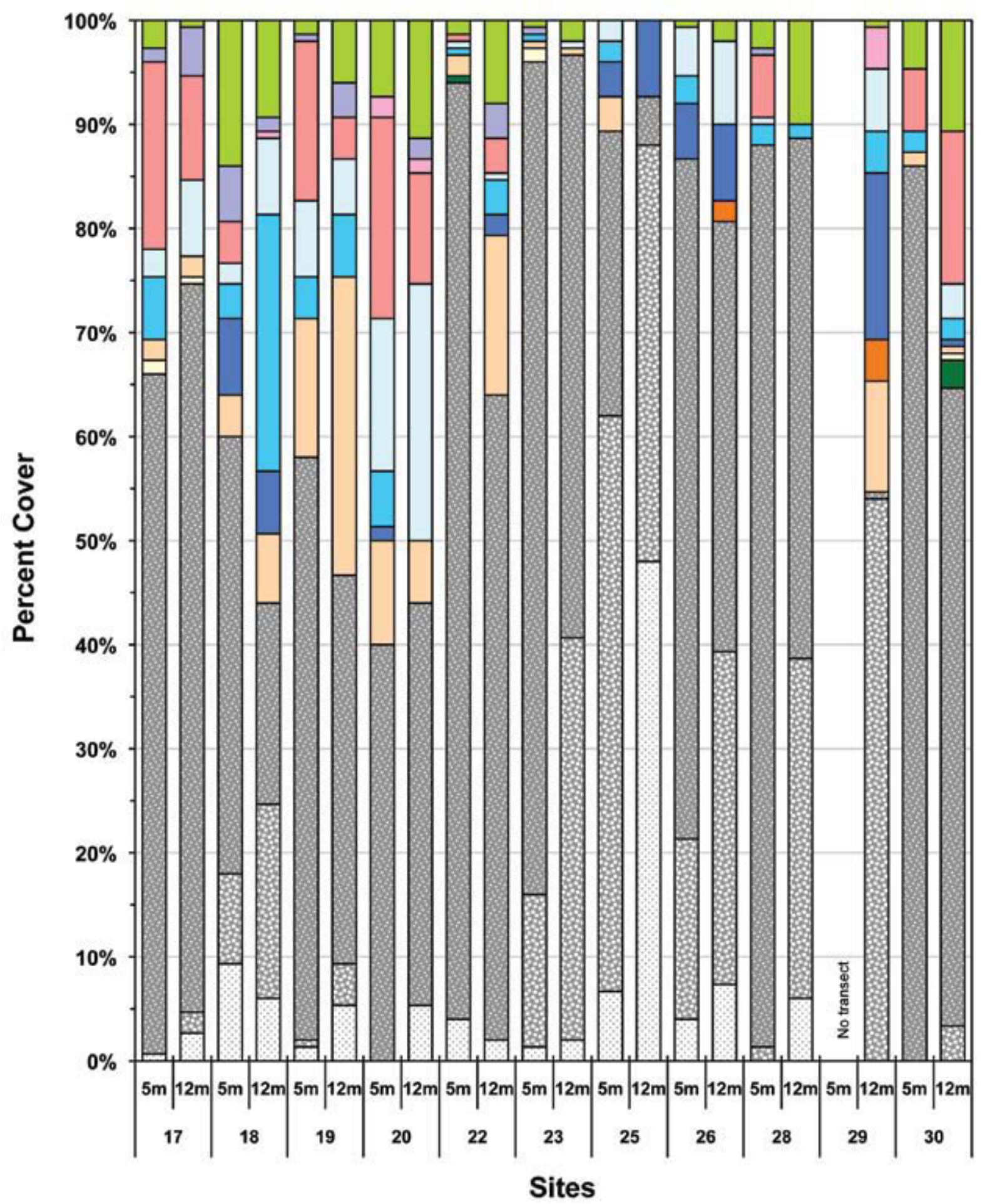

\begin{tabular}{lll}
\hline 口Massive coral & aSub-massive coral & aFoliose coral \\
aEncrusting coral & $\square$ Tabulate coral & $\square$ Digitate coral \\
$\square$ Branching coral & $\square$ Mushroom coral & $\square$ Soft coral \\
$\square$ Gorgonian coral & $\square$ Sponge & $\square$ Macroalgae \\
$\square$ Rock & $\square$ Rubble & $\square$ Sand \\
\hline
\end{tabular}

Figure 6 South Scott Reef habitat cover 


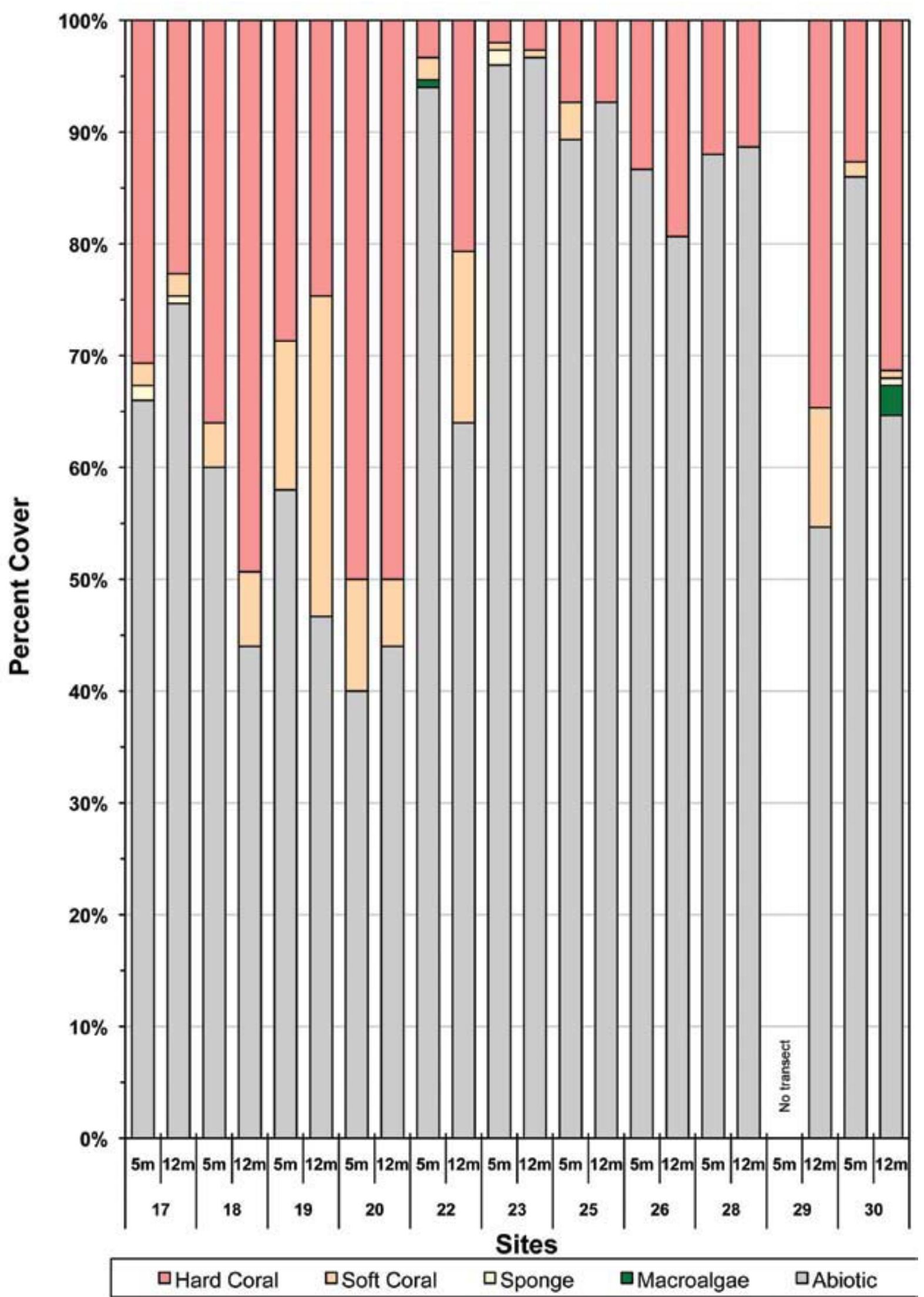

Figure 7 South Scott Reef grouped habitat cover 


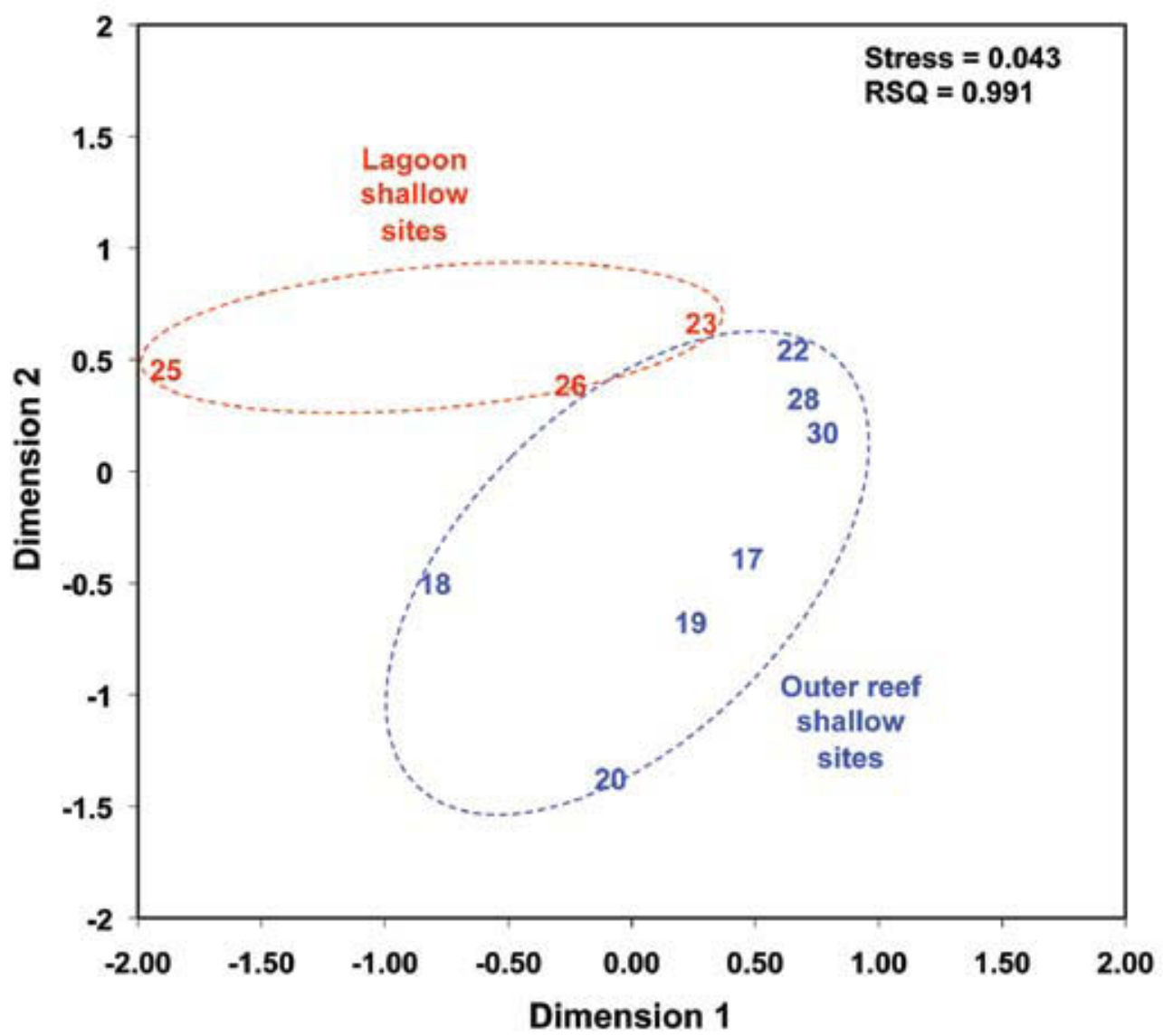

Figure 8 MDS Plot of South Scott Reef shallow transects

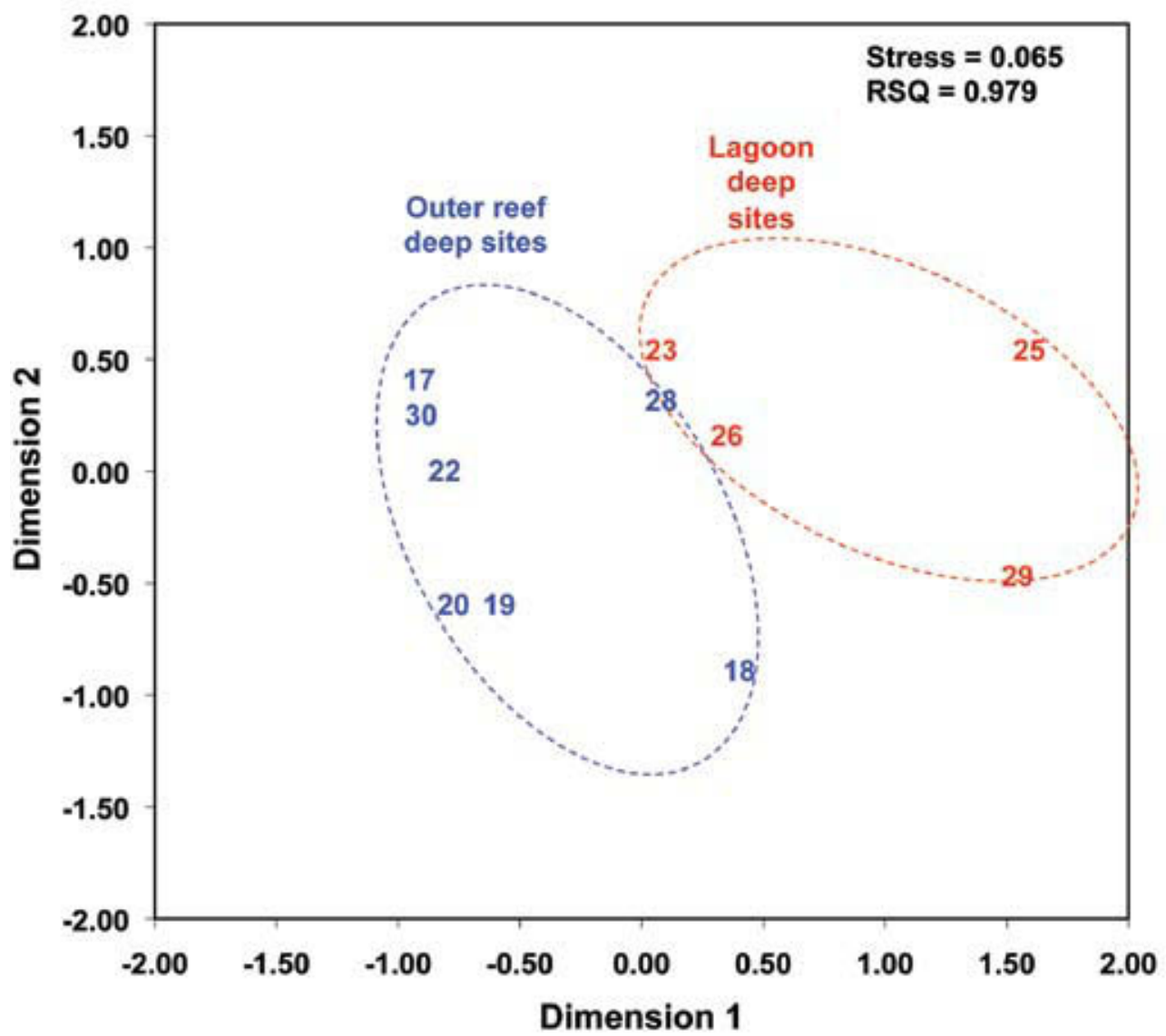

Figure 9 MDS Plot of South Scott Reef deep transects 


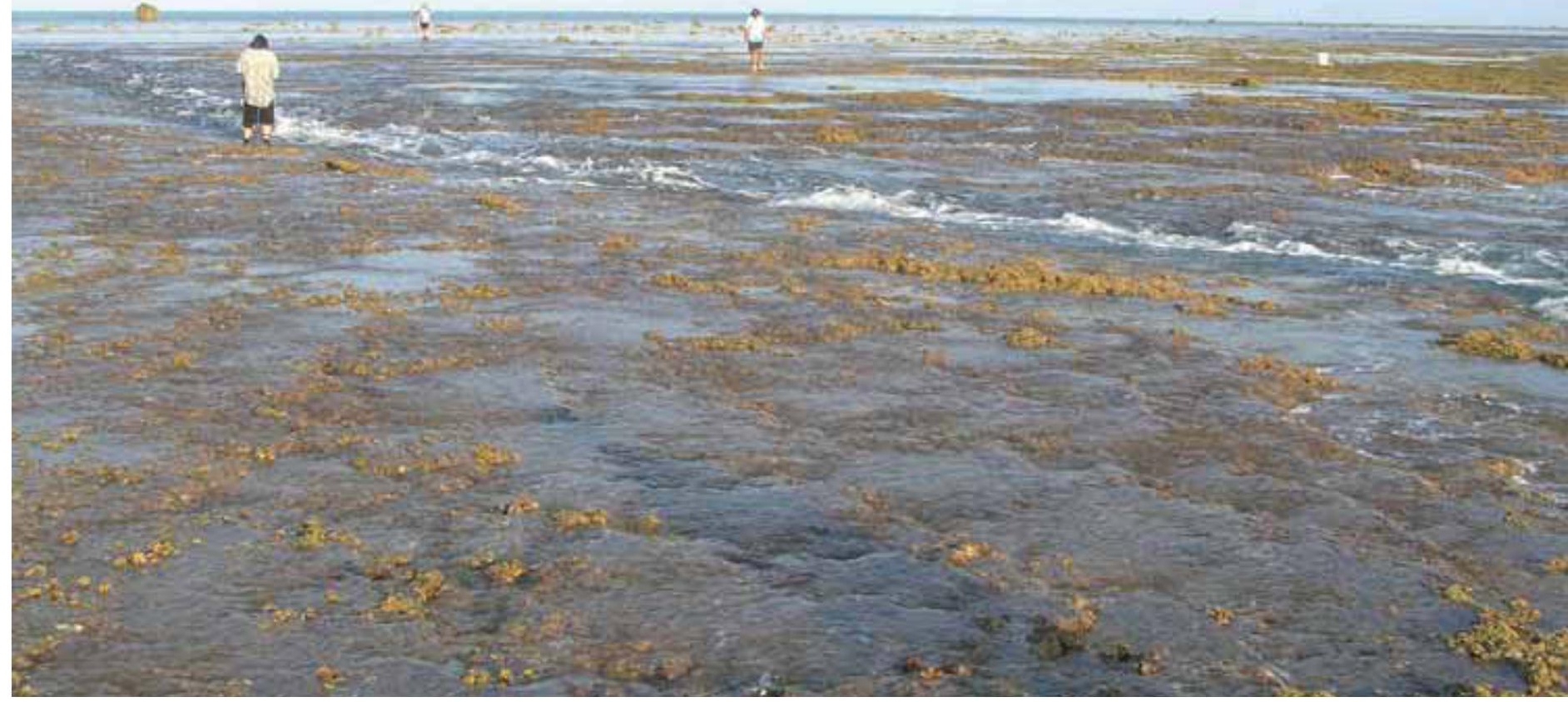

Above: Station 44, Mermaid Reef. Shallow drainage channels dissect the reef platform. (Photo: Clay Bryce)

\section{NORTH SCOTT REEF}

The general description of the physical characteristics of the seabed at each station for North Scott is presented in Table 3. The mean percentage cover by benthic habitat at each station transect is presented graphically by the 15 benthic categories graphically in Figure 10. The data is also presented as percentage cover by a reduced category data set, which amalgamates the abiotic, soft coral and hard coral categories resulting in a set of 5 categories in Figure 11.
Analysis of the data indicates that the outer reef and lagoon transects were distinctly different at both shallow and deep transects (see Figure 12 and Figure 13).

All stations at North Scott Reef were dominated by the abiotic categories sand, rubble and rock ranging from $65-95 \%$ cover (Figure 10). The hard corals were dominated by massive and encrusting corals as well as branching corals. Gorgonians were found at the shallow lagoon station 38 and were not recorded on any other transect in the four reefs surveyed.

Table 3 Transect topography at North Scott Reef

\begin{tabular}{l|l|l|l}
\hline Station & Habitat & Depth $(\mathbf{m})$ & Description \\
\hline 31 & Outer reef & 5 & $\begin{array}{l}\text { Heavily dissected reef with near vertical walls and rubble bases. } \\
\text { Heavily dissected reef with near vertical walls and rubble bases. }\end{array}$ \\
\hline 32 & Lagoon & $\begin{array}{l}12 \\
12\end{array}$ & $\begin{array}{l}\text { Bommie top with coral rubble. } \\
\text { Sandy seabed with coral bommies and rocky outcrops. }\end{array}$ \\
\hline 34 & Outer reef & 5 & $\begin{array}{l}\text { Heavily dissected reef with deep gutters and sandy patches. } \\
\text { Heavily dissected reef with deep gutters and patches of rubble. }\end{array}$ \\
\hline 36 & Outer reef & 5 & $\begin{array}{l}\text { Heavily dissected reef with undulating ridges and gutters. } \\
\text { Heavily dissected reef with deep gutters and flattened ridges. }\end{array}$ \\
\hline 38 & Lagoon & 5 & $\begin{array}{l}\text { Slope of small bommie. } \\
\text { Small lumps surrounded by coral sand and rubble. }\end{array}$ \\
\hline 39 & Lagoon & 5 & $\begin{array}{l}\text { Bommie slope with coral rubble. } \\
\text { Coral sand and rubble with several small rocky outcrops. }\end{array}$ \\
\hline
\end{tabular}




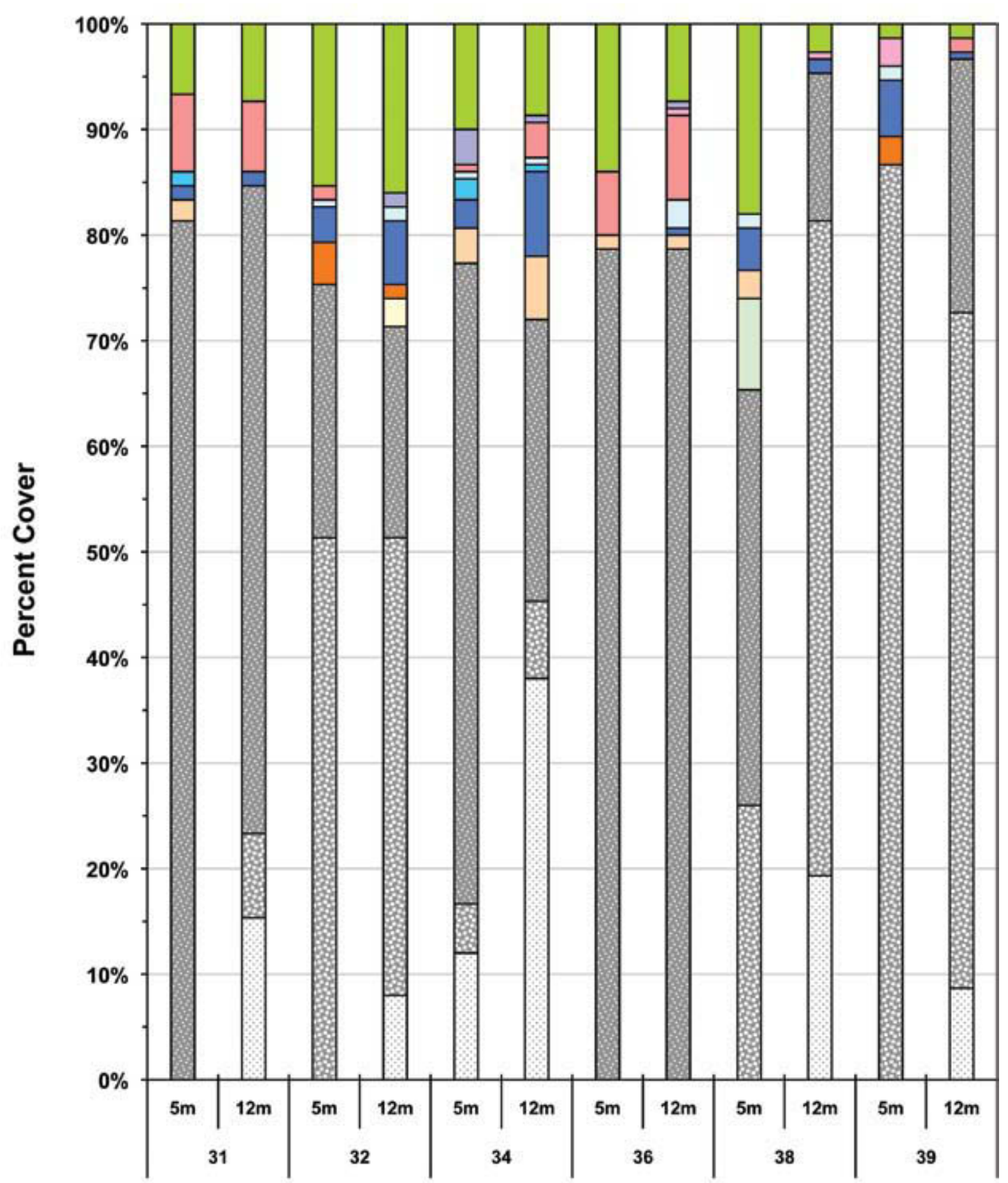

Sites

\begin{tabular}{lll}
\hline 口Massive coral & 口Sub-massive coral & 口Foliose coral \\
वEncrusting coral & $\square$ Tabulate coral & $\square$ Digitate coral \\
$\square$ Branching coral & $\square$ Mushroom coral & $\square$ Soft coral \\
$\square$ Gorgonian coral & $\square$ Sponge & $\square$ Macroalgae \\
$\square$ Rock & $\square$ Rubble & $\square$ Sand \\
\hline
\end{tabular}

Figure 10 North Scott Reef habitat cover 


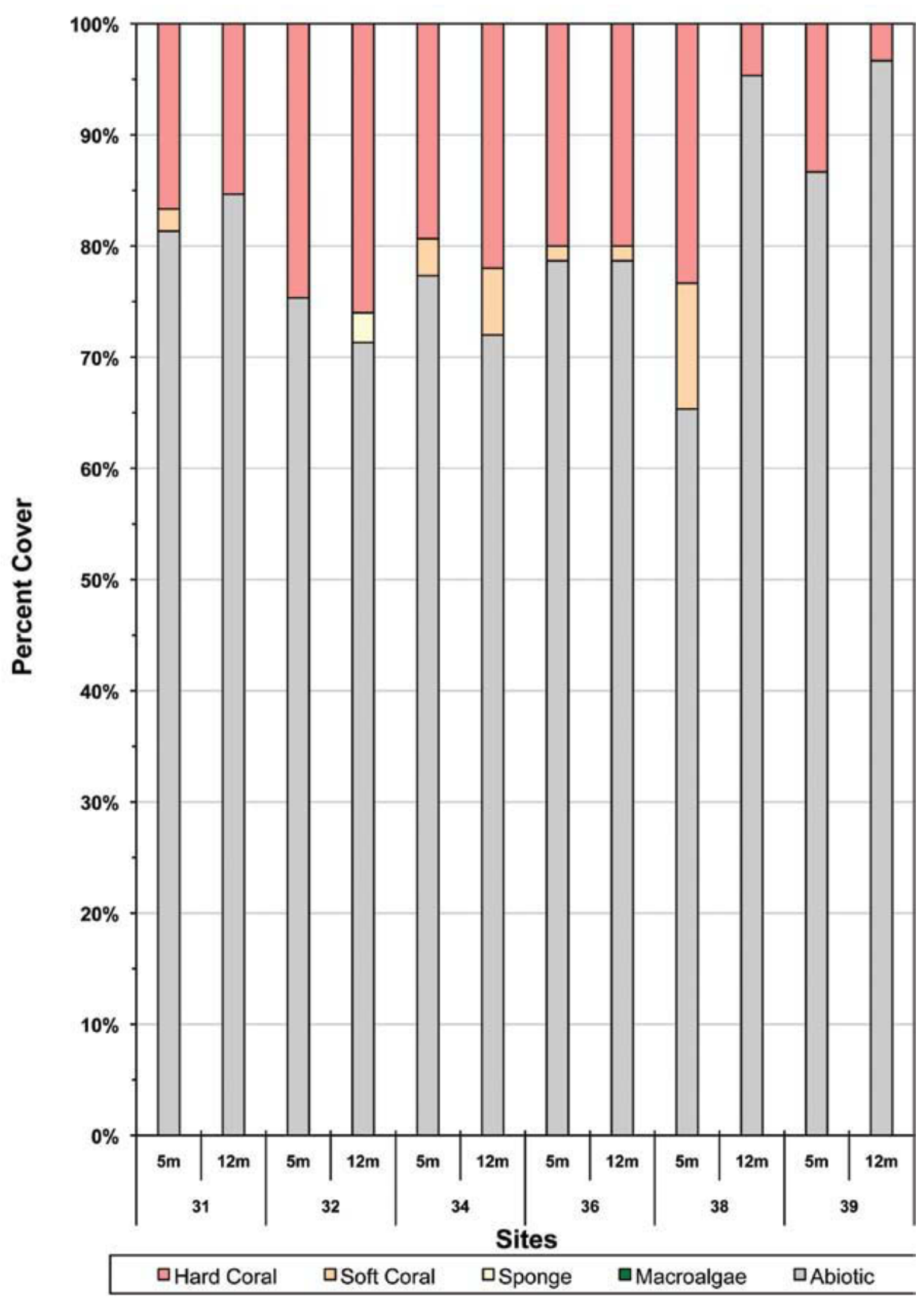

Figure 11 North Scott Reef grouped habitat cover 


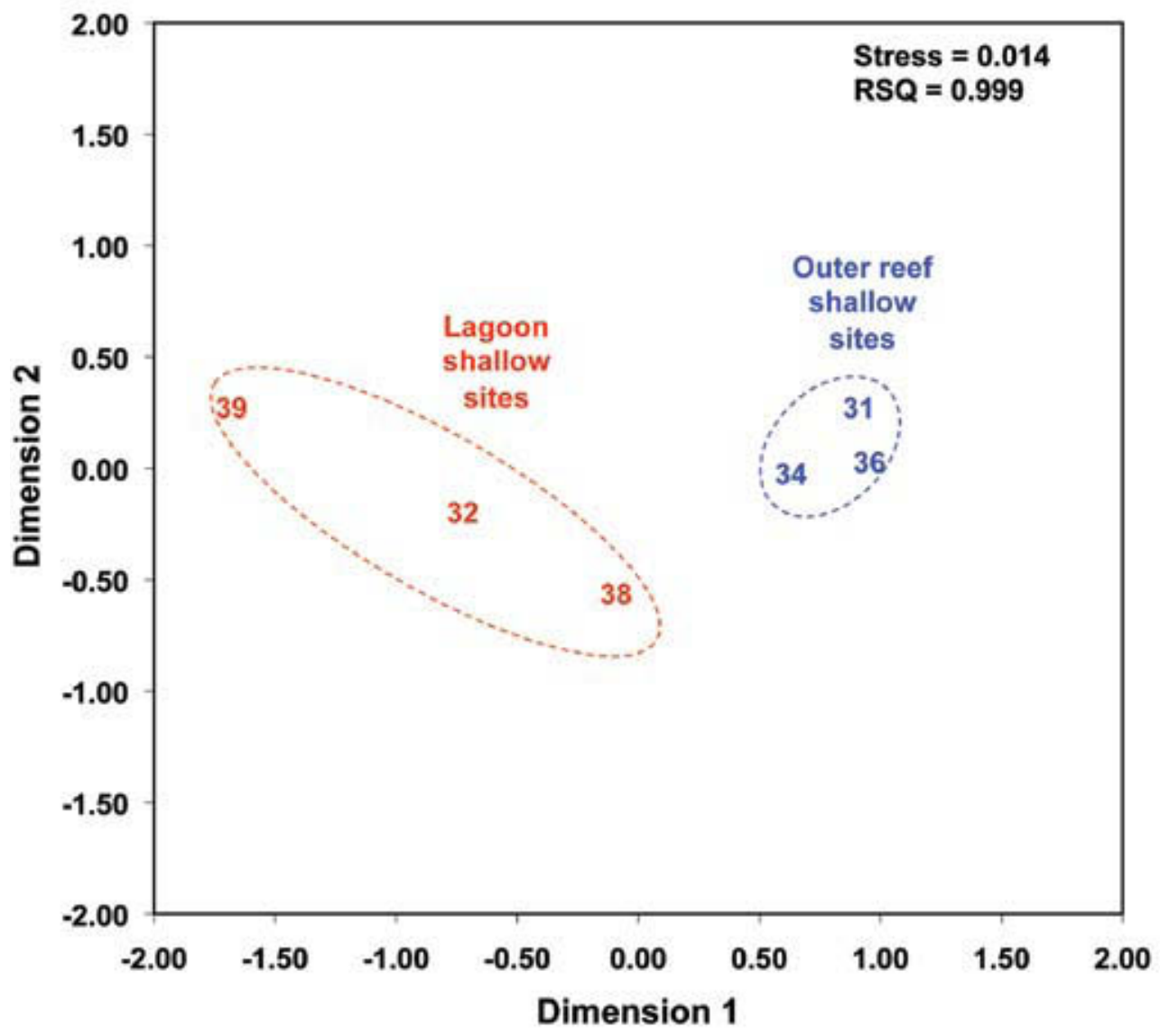

Figure 12 MDS Plot of North Scott Reef shallow transects

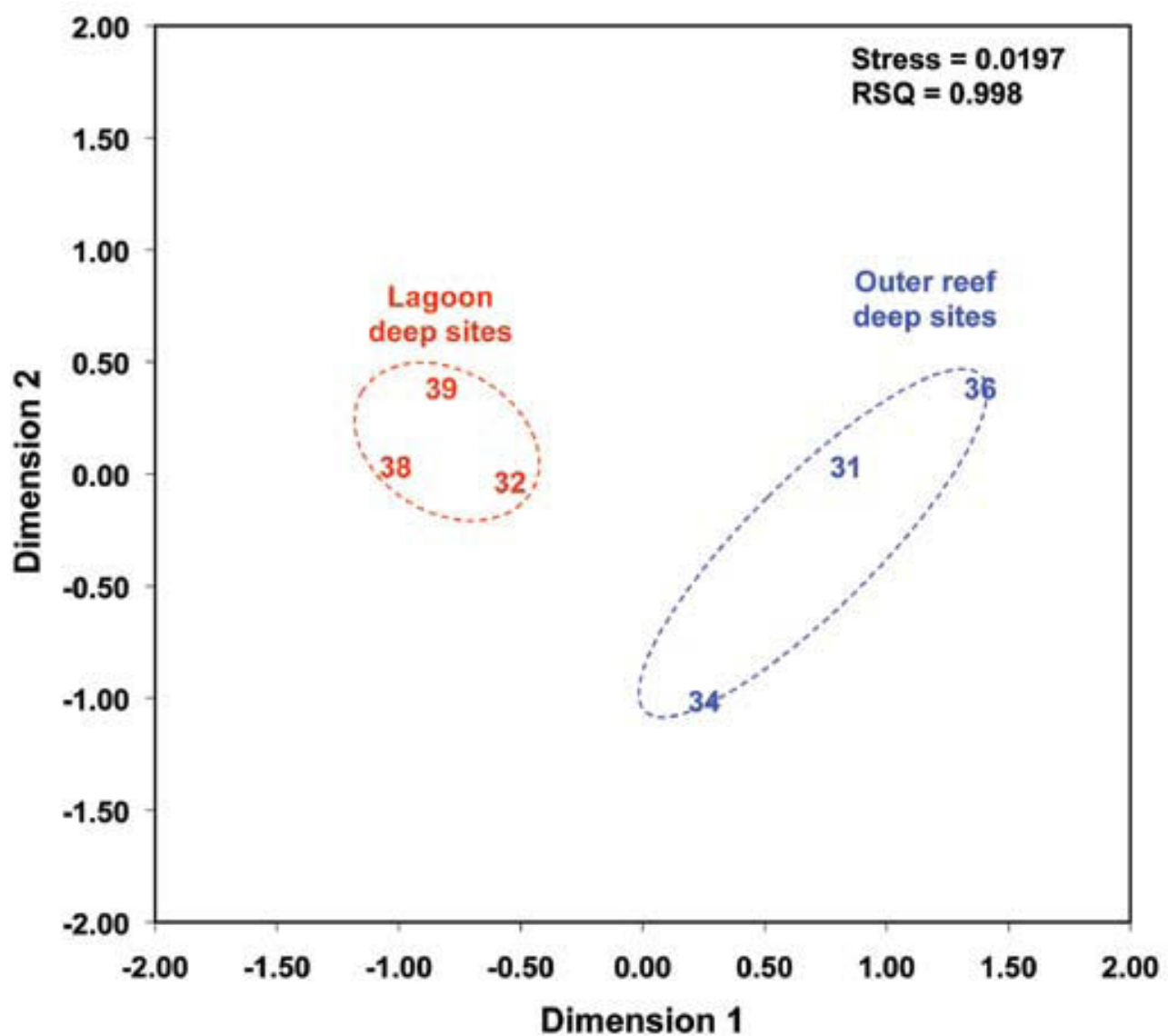

Figure 13 MDS Plot of North Scott Reef deep transects 


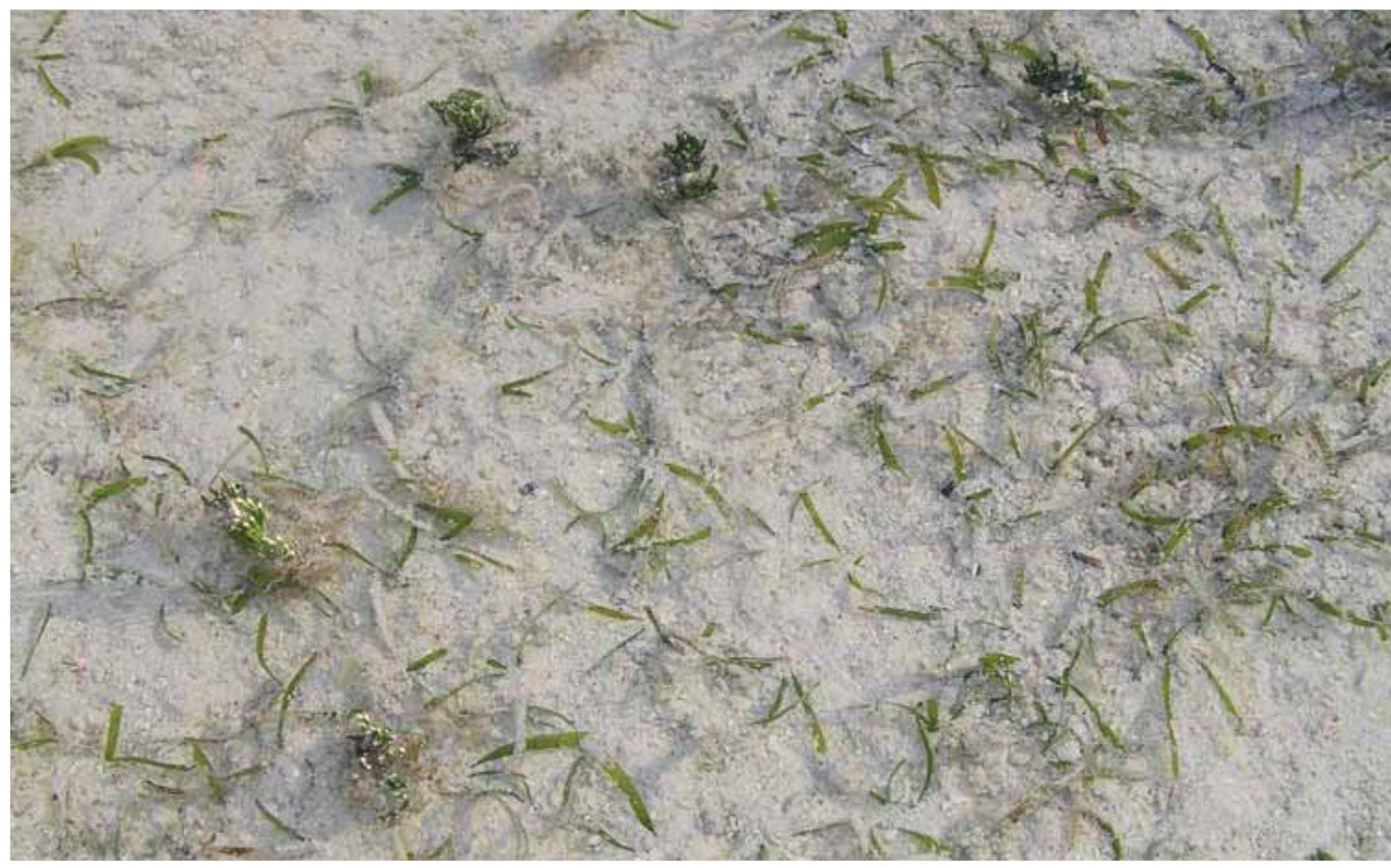

Above: Station 24, South Scott Reef. Thalassia seagrass. (Photo: Clay Bryce) 


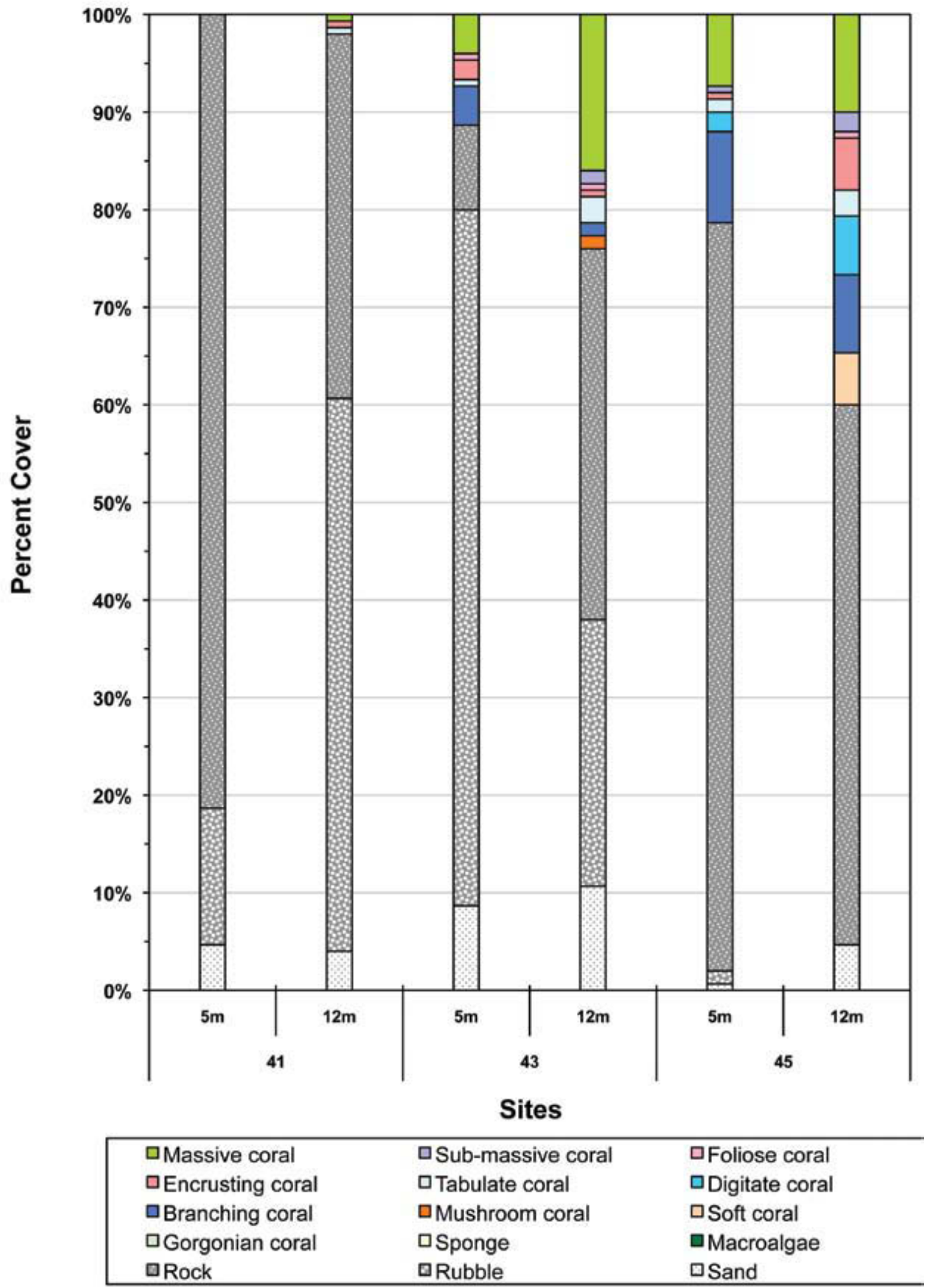

Figure 14 Seringapatam Reef habitat cover 


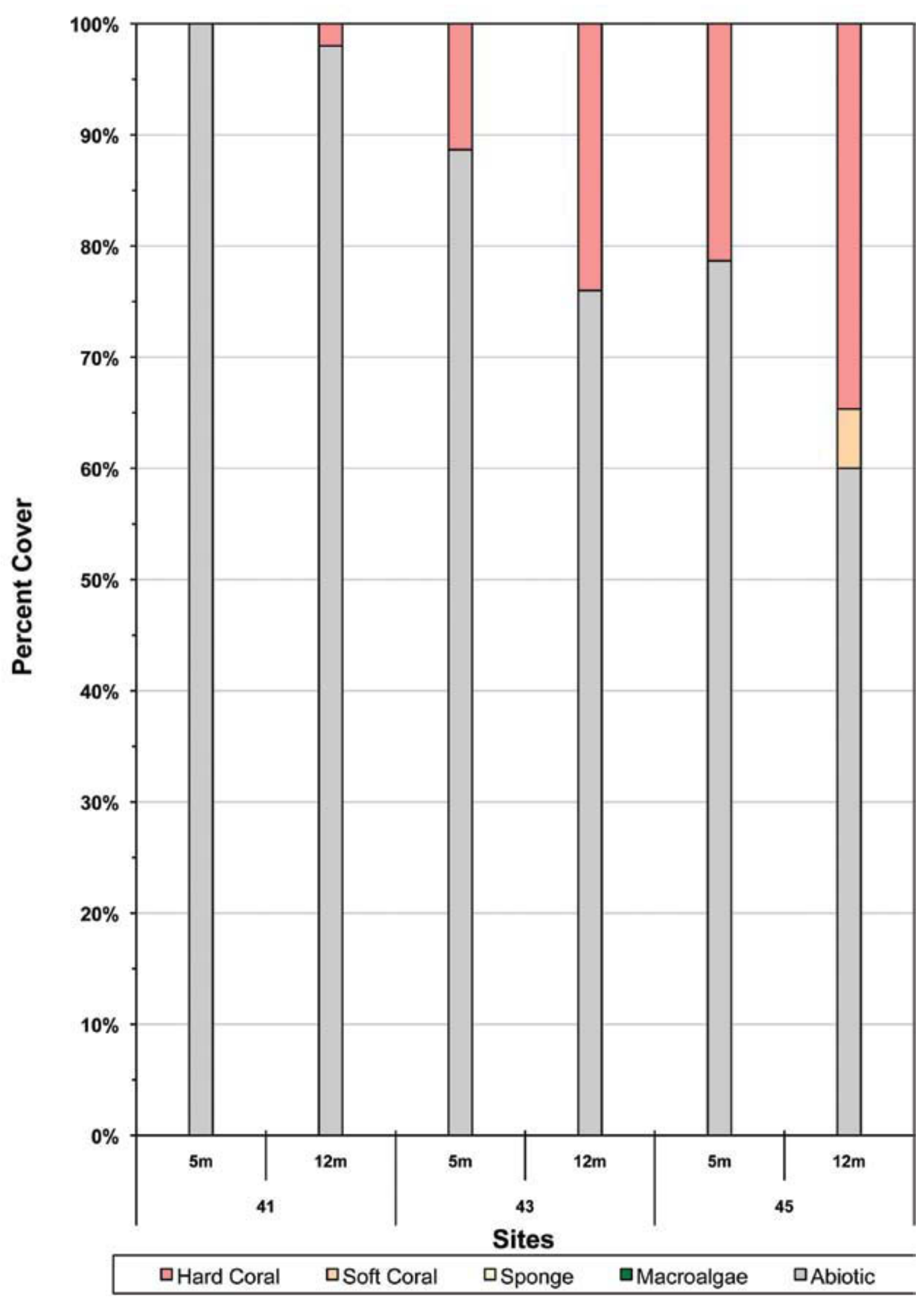

Figure 15 Seringapatam Reef Grouped habitat cover 


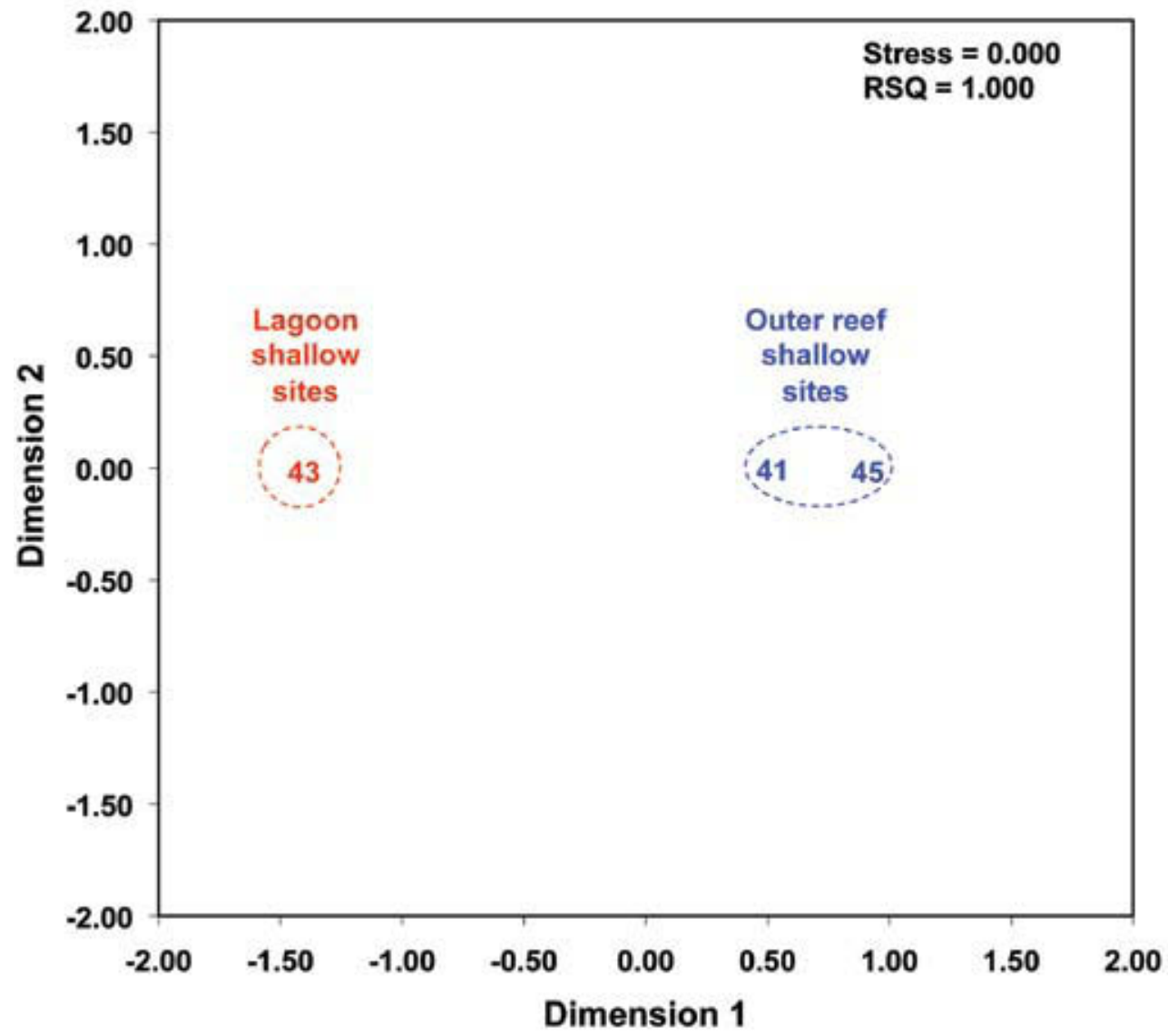

Figure 16 MDS Plot of Seringapatam Reef shallow transects

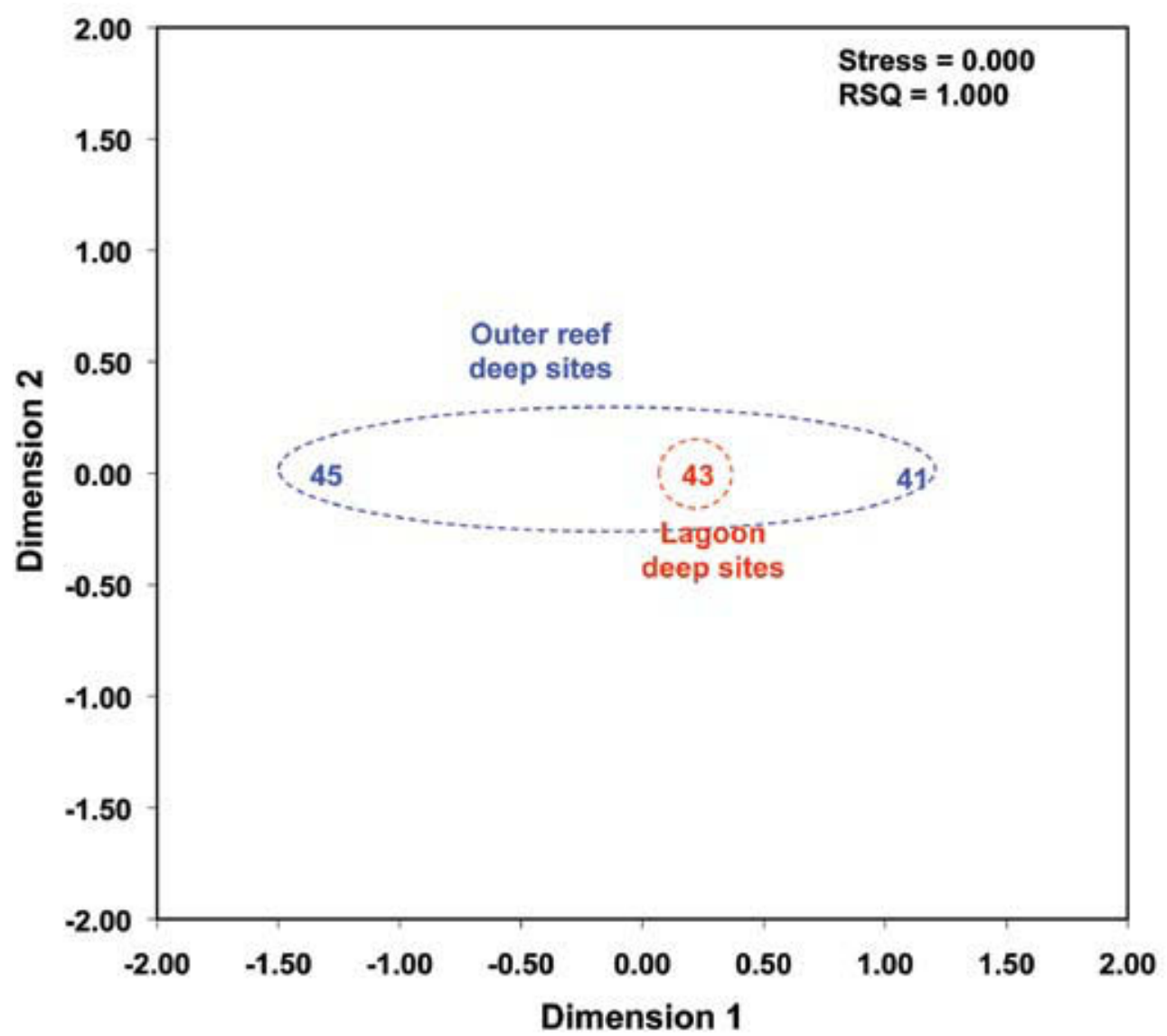

Figure 17 MDS Plot of Seringapatam Reef deep transects 